\title{
Comparison of carbohydrate utilization in man using indirect calorimetry and mass spectrometry after an oral load of $100 \mathrm{~g}$ naturally-labelled $\left[{ }^{13} \mathrm{C}\right]$ glucose
}

\author{
BY J. R. EBINER, K. J. ACHESON, A. DOERNER, E. MAEDER, \\ M. J. ARNAUD, E. JÉQUIER AND J. P. FELBER \\ Divisions de Biochimie Clinique et de Physiologie Clinique, \\ Département de Médecine, CHUV, Io I Lausanne, Switzerland, and \\ Laboratoire Nestlé, I8I 4 La-Tour-de-Peilz, Switzerland
}

(Received 22 August 1978 - Accepted 26 September 1978)

I. Carbohydrate (CHO) oxidation was measured simultaneously in a group of five normal subjects after an oral load of $100 \mathrm{~g}$ naturally-labelled $\left[{ }^{13} \mathrm{C}\right] \mathrm{glucose}$, using indirect calorimetry and mass spectrometry.

2. CHO utilization, calculated from the results of indirect calorimetry, increased $30 \mathrm{~min}$ after the glucose load to reach a peak at 90 min. It then decreased to reach basal values at $380 \mathrm{~min}$. Cumulative total $\mathrm{CHO}$ oxidation at 480 min was $83 \pm 8 \mathrm{~g}$, and $\mathrm{CHO}$ oxidized above basal levels, $37 \pm 3 \mathrm{~g}$.

3. Enrichment of expired carbon dioxide with ${ }^{13} \mathrm{C}$ began at $60 \mathrm{~min}$ and maximum values were observed at $270 \mathrm{~min}$. At $480 \mathrm{~min}$, cumulative $\mathrm{CHO}$ oxidation measured by use of $\left[{ }^{13} \mathrm{C}\right] \mathrm{glucose}$ was $29 \mathrm{~g}$. The difference from calorimetric values can be attributed in part to the slow isotopic dilution in the glucose and bicarbonate pools.

4. Thus, approximately $30 \%$ of the glucose load was oxidized during the $8 \mathrm{~h}$ after its ingestion and this accounts for a significant part of the increased $\mathrm{CHO}$ oxidation $(37 \mathrm{~g})$, as measured by indirect calorimetry.

There are two major sources of metabolic fuel, glucose and free fatty acids (FFA) whose energy is used for vital activities. Measurement of over-all utilization of carbohydrate yields useful information on the fate of this fuel in normal and pathological cases. Two different approaches are usually used to estimate carbohydrate utilization, i.e. indirect calorimetry and isotopic methods. Continuous indirect calorimetry, based on the measurement of oxygen and carbon dioxide in the expired air, yields information on over-all carbohydrate (CHO) and lipid utilization, particularly under dynamic conditions such as during oral glucose tolerance tests (OGTT). However, unlike isotopic methods, indirect calorimetry cannot be used to differentiate between the endogenous or exogenous origin of the substrate (Gomez et al. 1972; Müller-Hess et al. 1975; Felber et al. 1977). Radioisotopes have been used for in vitro and in vivo animal studies (Searle et al. 1956; Eaton \& Steinberg, 196I; Steele, Winkler et al. 1968), but since their use is limited in humans, interest has been focused on the use of non-radioactive isotopes. The non-radioactive isotope of carbon, ${ }^{13} \mathrm{C}$, can be used for human investigation. There are some natural sugars, e.g. maize and cane sugar, in which the ratio ${ }^{13} \mathrm{C}:{ }^{12} \mathrm{C}$ is higher than that of other sugars (Smith \& Epstein, I97I). If such a sugar is used for OGTT, it is possible to collect the expired $\mathrm{CO}_{2}$ and measure the variations in the ratio ${ }^{19} \mathrm{C}:{ }^{12} \mathrm{C}$ during the experiment. These variations reflect the fate of the exogenous glucose (Lefebvre et al. 1975; Mosora et al. 1976).

The purpose of this study was to try to quantify endogenous and exogenous CHO oxidation in control subjects by using the two methods simultaneously. 


\section{MATERIALS AND METHODS}

Five healthy subjects, one man and four women between 18 and 24 years of age, volunteered for this study (Table 1 ). All were within $15 \%$ of their ideal body-weight according to normal values from Tables 2 and 3 of the Metropolitan Life Insurance Company (1959) and none had any family history of diabetes.

\section{OGTT with naturally-labelled $\left[{ }^{13} \mathrm{C}\right]$ glucose ( $\left.100 \mathrm{~g}\right)$}

The normal diet of the subject did not include maize or cane sugar during the month preceding the test.

The subjects, who were asked to collect their overnight urine, arrived at the hospital at 07.00 hours after a $\mathrm{I} 2 \mathrm{~h}$ fast and were allowed to rest for approximately $\mathrm{I} \mathrm{h}$ before the test began. After baseline measurements lasting $30 \mathrm{~min}$, they drank a glucose solution of I00 g naturally-labelled $\left[{ }^{13} \mathrm{C}\right]$ glucose (Fluka, Buchs, Switzerland) in $400 \mathrm{ml}$ water. Continuous indirect calorimetric measurements were made for another $4 \mathrm{~h}$ and then at regular intervals until the eighth hour.

A second urine collection was made at the end of the $4 \mathrm{~h}$ continuous measurements.

Indirect calorimetry was performed as described by Gomez et al. (1972) and Felber et al. (1977) of which some details are given later. A transparent-plastic, ventilated hood was lowered over the subject's head and secured around his neck with a piece of air-tight cloth. A slight negative pressure was maintained in the hood to prevent expired air leaking out. The air-flow through the hood was measured using a pneumotachograph and samples of the outflowing air were continuously taken to monitor $\mathrm{O}_{2}$ and $\mathrm{CO}_{2}$ concentrations, using a paramagnetic and infrared analyser respectively. Using the calorimetric results and the urinary nitrogen, it was possible to calculate the non-protein respiratory quotient (NP-RQ) and then the oxidation rates of $\mathrm{CHO}$ and lipid, using the tables of Lusk (Lusk, I924).

Integration of the continuous measurements was recorded every $5 \mathrm{~min}$ for the whole duration of the test. The $\mathrm{CHO}$ oxidation rate was determined every $30 \mathrm{~min}$, from -30 to $240 \mathrm{~min}$, each $30 \mathrm{~min}$ period being the mean of six integrated periods of $5 \mathrm{~min}$.

\section{Blood measurements}

Blood samples were taken at $-30,0,30,60,90,120,150,180,210,240,360$ and 480 min for glucose, insulin and FFA determinations. Blood glucose was measured using the hexokinase method (Slein, 1965) and plasma insulin by radioimmunoassay according to Hales \& Randle (1963). Plasma FFA were extracted using the method of Dole \& Meinertz (I960) and determined according to the method of Heindel et al. (I974).

\section{Isotopic method}

To determine the ratio ${ }^{13} \mathrm{C}:{ }^{12} \mathrm{C}$ in the expired $\mathrm{CO}_{2}$, a known fraction of the expired air was bubbled through: $60 \mathrm{ml} \mathrm{I}$ M-sodium hydroxide (Titrisol ${ }^{\circledR}$; Merck, Darmstadt, Germany) to absorb the $\mathrm{CO}_{2}$. The samples were then kept at $-20^{\circ}$ until analysed.

The I $\mathrm{M}-\mathrm{NaOH}$ sample was thawed and $2-5 \mathrm{ml}$ were taken and put into an evacuating flask. The flask was connected to a vacuum line to de-gas the sample and then put in liquid $\mathrm{N}_{2}$. The vacuum was broken so that $3 \mathrm{ml} 3 \mathrm{M}$-sulphuric acid could be added. This froze in a layer immediately above the $\mathrm{NaOH}$. The flask was re-evacuated on the vacuum line, after which it was warmed to allow the frozen reagents to thaw and react together to produce $\mathrm{CO}_{2}$. Finally, the evacuated flask was put into an ethanol and dry-ice bath at 


\section{Calorimetry and isotopes in $\mathrm{CHO}$ utilization}

Table I. Details of subjects

$\begin{array}{cccccc}\text { Subjects } & \text { Sex } & \begin{array}{c}\text { Age } \\ \text { (years) }\end{array} & \begin{array}{c}\text { Height } \\ (\mathrm{m})\end{array} & \begin{array}{c}\text { Wt } \\ (\mathrm{kg})\end{array} & \begin{array}{r}\text { Body-wt } \\ (\% \text { ideal } \\ \text { body-wt)* }\end{array} \\ \text { B.F. } & + & 20 & \mathrm{I} \cdot 795 & 70 \cdot 5 & 106 \\ \text { J.E. } & + & 24 & \mathrm{I} \cdot 690 & 55 \cdot 0 & 93 \\ \text { L.J. } & +5 & 22 & \mathrm{I} \cdot 770 & 67.7 & 98 \\ \text { M.C. } & + & 20 & \mathrm{I} \cdot 680 & 50 \cdot 0 & 86 \\ \text { R.C. } & + & \mathrm{I} 8 & \mathrm{I} \cdot 650 & 59 \cdot 2 & 106 \\ & * & \end{array}$

$-80^{\circ}$ to freeze the water which was formed and prevent its introduction into the mass spectrometer (MS $20 \mathrm{AEI}$ ).

\section{Analysis of mass spectrometry}

Using the information obtained for each sample it was possible to calculate the following:

$$
\begin{gathered}
\text { atom } \% \text { sample }=\frac{{ }^{13} \mathrm{C} \text { sample }}{{ }^{12} \mathrm{C} \text { sample }+{ }^{13} \mathrm{C} \text { sample }} \times 100, \\
\text { atom } \% \text { standard }=\frac{{ }^{13} \mathrm{C} \text { standard }}{{ }^{12} \mathrm{C} \text { standard }+{ }^{13} \mathrm{C} \text { standard }} \times 100, \\
\text { atom } \% \text { excess }=\text { atom } \% \text { sample }- \text { atom } \% \text { standard. }
\end{gathered}
$$

The standard was a potassium carbonate liquid reference (Fluka). For each sample taken, at time $t$, the atom \% excess was referred to that taken at zero time (the time when no exogenous glucose was present in the organism) to obtain the change in $(\Delta)$ atom $\%$ excess:

$$
\triangle \text { atom } \% \text { excess }=\text { atom } \% \text { excess }_{t} \text {-atom } \% \text { excess }_{0} .
$$

There is no major difference between these calculations and those used by Lefebvre et al. (1975), where enrichment is expressed as ${ }^{13} \mathrm{C} \%$ according to Craig's (1957) formula. This formula is mathematically related to the atom $\%$ excess value used in the present work.

\section{Quantification of the mass spectrometry results}

In order to compare the calorimetric results with those from the mass spectrometer, it was necessary to convert atom $\%$ excess $(\%)$ into glucose oxidation $\mathrm{mg} / \mathrm{min}$.

It can be established that:

$$
\frac{\dot{Q} \text { exogenous glucose oxidized }}{Q \text { glucose load }}=\frac{\dot{Q}^{13} \mathrm{C}_{\left(\mathrm{CO}_{2}\right)}}{Q^{13} \mathrm{C}_{(\mathrm{load})}},
$$

where $\dot{Q}^{13} \mathrm{C}_{\mathrm{CO}_{2}}$, is the amount of ${ }^{13} \mathrm{Cg} / \mathrm{min}$ in the expired $\mathrm{CO}_{2}$ resulting from the oxidation of exogenous glucose.

$$
\dot{Q}^{13} \mathrm{C}_{\left(\mathrm{CO}_{2}\right)}=\frac{\dot{V}_{\mathrm{CO}_{2}} \times \sqrt{2}}{22 \cdot 26} \times \Delta \text { atom } \% \text { excess } \times \frac{1}{100}
$$

where $\dot{\mathrm{V}}_{\mathrm{O}_{2}}$ is the volume of $\mathrm{CO}_{2}$ produced $/ \mathrm{min}, \mathrm{I} 2$ is the atomic weight of $\mathrm{C}, 22 \cdot 26$ is the volume of 1 mol $\mathrm{CO}_{2}$ ( 1 ; standard temperature and pressure). The $Q^{13} \mathrm{C}$ of the load is the amount of ${ }^{13} \mathrm{C}(\mathrm{g})$ in $100 \mathrm{~g}$ of the glucose load.

Thus:

$$
\dot{Q}^{13} \mathrm{C}_{\text {(load) }}=100 \times 0.4 \times \text { atom } \% \text { excess glucose } \times \frac{\mathrm{I}}{100},
$$




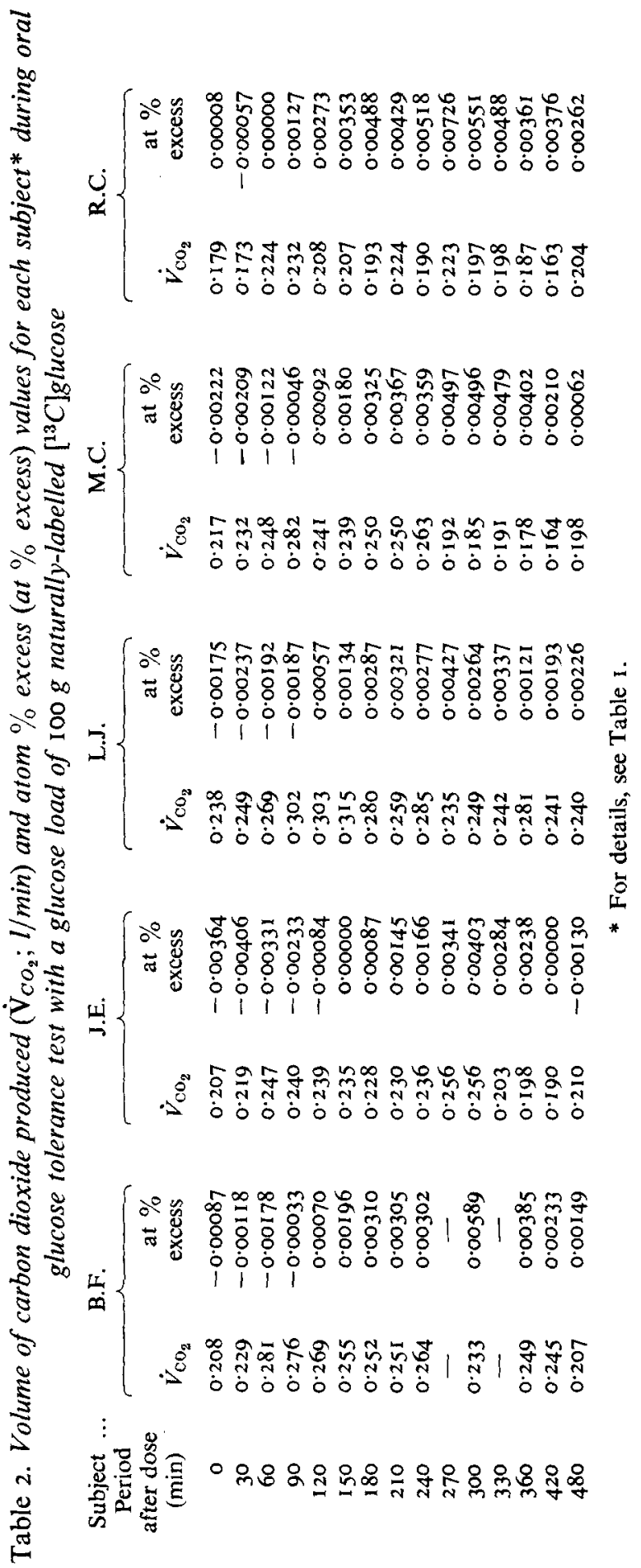


where 0.4 represents the fractional weight of $\mathrm{C}$ in glucose. From the above equations, it follows that:

$$
\dot{Q} \text { exogenous glucose oxidized }=\frac{\frac{\dot{V}_{\mathrm{CO}_{2}} \times 12}{22 \cdot 26} \times \Delta \text { atom } \% \text { excess }}{0 \cdot 4 \times \text { atom } \% \text { excess glucose }} .
$$

The mean $\dot{V}_{\mathrm{Co}_{2}}(1 / \mathrm{min})$ and the atom \% excess per period, for each subject is presented in Table 2 .

\section{RESULTS}

OGTT with $\left[{ }^{13} \mathrm{C}\right]$ glucose in five normal subjects

Fig. I illustrates $\mathrm{CHO}$ and lipid oxidation rates as well as plasma glucose, insulin and FFA levels during the $8 \mathrm{~h}$ test.

The mean plasma glucose value at zero time was $830 \pm 30 \mathrm{mg} / \mathrm{l}$. This increased after the load and reached a peak $(1190 \pm 50 \mathrm{mg} / \mathrm{l})$ at $30 \mathrm{~min}$. It then decreased and reached basal levels $(810 \pm 70 \mathrm{mg} / \mathrm{l})$ at $180 \mathrm{~min}$. Insulin levels increased from $12 \pm 2 \mu \mathrm{U} / \mathrm{ml}$ at zero time to a peak value $(87 \pm \mathrm{I} 3 \mu \mathrm{U} / \mathrm{ml}) 30 \mathrm{~min}$ later. Its return to basal values was more delayed than that for blood glucose. At $240 \mathrm{~min}$ after the glucose load, plasma immunoreactive insulin was $29 \pm 14 \mu \mathrm{U} / \mathrm{ml}$ and at $360 \mathrm{~min}, 15 \pm 3 \mu \mathrm{U} / \mathrm{ml}$. Basal FFA levels ranged from 190 to $680 \mu \mathrm{mol} / \mathrm{l}$ with a mean ( \pm SEM) of $416 \pm 80 \mu \mathrm{mol} / \mathrm{l}$. After the glucose load, FFA levels decreased and reached minimum values ( $134 \pm 17$ and $117 \pm 17 \mu \mathrm{mol} / \mathrm{l}$ ) between 90 and $\mathrm{I} 20 \mathrm{~min}$. They then increased progressively until the end of the test $(774 \pm 12 \mathrm{I} / \mathrm{mol} / \mathrm{l})$. In each instance, the increase in FFA occurred when insulin had returned to its basal level. Table 2 shows the $\mathrm{CO}_{2}$ production rate and the $\triangle$ atom $\%$ excess for each subject.

The $\mathrm{CHO}$ oxidation rate at the beginning of the test, calculated from the indirect calorimetry results, was $97 \pm 14 \mathrm{mg} / \mathrm{min}$. After the load, CHO utilization increased significantly after $60 \mathrm{~min}(2 \mathrm{I} 4 \pm 22 \mathrm{mg} / \mathrm{min})$ and reached maximum values between 90 and I $80 \mathrm{~min}$ ( 250 and $228 \mathrm{mg} / \mathrm{min}$ respectively). It then decreased gradually to basal levels by the end of the test.

In contrast, a significant increase in the utilization (I $8.4 \pm 6.2 \mathrm{mg} / \mathrm{min}$ ) of $\left[{ }^{13} \mathrm{C}\right] \mathrm{glucose}$ was only observed at $90 \mathrm{~min}$. Peak utilization (I $5.3 \pm 7.3 \mathrm{mg} / \mathrm{min}$ ) was reached at $270 \mathrm{~min}$ and at the end of the test it was $45 \pm 6.7 \mathrm{mg} / \mathrm{min}$.

Lipid oxidation was $56 \pm 5 \mathrm{mg} / \mathrm{min}$ at zero time. This rapidly decreased to $30 \pm 13 \mathrm{mg} / \mathrm{min}$ at $60 \mathrm{~min}$. Minimum values oscillated between $20 \pm 6$ and $\mathrm{I} 6 \pm 7 \mathrm{mg} / \mathrm{min}$ from 90 to $180 \mathrm{~min}$ and then increased progressively until the end of the test $(59 \pm 2 \mathrm{mg} / \mathrm{min})$.

\section{Cumulative $\mathrm{CHO}$ utilization}

Cumulative values for CHO oxidation during the $480 \mathrm{~min}$ OGTT are shown in Table 3 and Fig. 2. Total utilization was $38 \pm 3 \mathrm{~g}$ after $\mathrm{I} 80 \mathrm{~min}$ and $83 \pm 8 \mathrm{~g}$ after $480 \mathrm{~min}$. If the basal value is subtracted, $2 \mathrm{I} \pm \mathrm{I} \mathrm{g}$ and $37.2 \pm 2 \mathrm{~g} \mathrm{CHO}$ were oxidized at $\mathrm{I} 80$ and $480 \mathrm{~min}$ respectively. Mass spectrometry gave values of $6 \cdot 4 \pm 0.6 \mathrm{~g}$ at $\mathrm{I} 80 \mathrm{~min}$ and $29 \cdot 2 \pm \mathrm{I} \cdot 5 \mathrm{~g}$ after $480 \mathrm{~min}$.

\section{Energy expenditure}

The energy produced by the oxidation of the three substrates was calculated for periods of 30 and $60 \mathrm{~min}$ (Fig. 3).

The mean ( \pm SEM) basal energy expenditure was $4.86 \pm 0.2 \mathrm{I} \mathrm{kJ} / \mathrm{min}$ and the substrate contribution was $34 \pm 4,45 \pm 3$ and $2 \mathrm{I} \pm 5 \%$ for $\mathrm{CHO}$, lipid and protein respectively.

Maximal expenditure occurred from 60 to $90 \mathrm{~min}(5 \cdot 77 \pm 0.29 \mathrm{~kJ} / \mathrm{min})$, at which time 

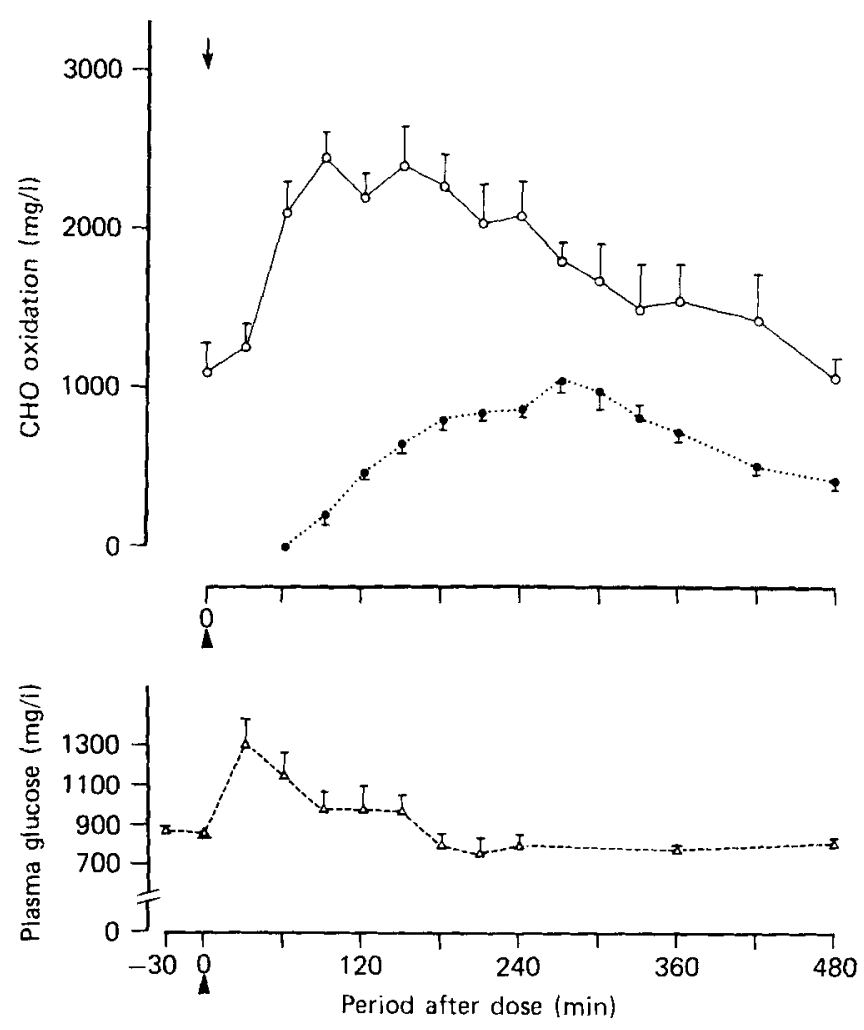

For figure legend, see opposite page.

$74 \pm 3 \%$ of the energy came from $\mathrm{CHO}$ oxidation, $\mathrm{I} 3 \pm 3 \%$ from lipid and $13 \pm 3 \%$ from protein.

The $\mathrm{CHO}$ contribution increased to $77 \%$ and that of lipid decreased to $9 \%$ between 120 and $150 \mathrm{~min}$, after which there was a progressive return to normal values at $480 \mathrm{~min}$ $(4.69 \pm 0.25 \mathrm{~kJ} / \mathrm{min}$, with a relative contribution of $35 \pm 3 \% \mathrm{CHO}, 50 \pm \mathrm{I} \cdot 5 \%$ lipid and $15 \pm 3 \%$ proteins).

\section{DISCUSSION}

A delay in the rate of $\mathrm{CHO}$ utilization with respect to the peak in blood glucose has been previously reported using different methods, i.e. $\left[{ }^{14} \mathrm{C}\right]$ glucose (Baker et al. 1954; Searle et al. 1956), $\left[{ }^{13} \mathrm{C}\right]$ glucose (Lefebvre et al. 1975) and indirect calorimetry (Felber et al. 1977). This delay is a result of several factors such as: (I) the slow switch over, in muscle tissue, from FFA oxidation in the fasting state to glucose oxidation in the fed state; (2) the delay due to glucose polymerization to glycogen which would precede oxidative degradation, as suggested by Beloff-Chain et al. (1955) in their study on rat diaphragm muscle.

The cumulative values of the CHO oxidized (Table 3), measured by indirect calorimetry, are of the same order of magnitude as the total splanchnic glucose output reported by Felig et al. (1975). Values in the present study which show that $38 \pm 3 \mathrm{~g} \mathrm{CHO}$, expressed as glucose, were used during the $3 \mathrm{~h}$ after the $100 \mathrm{~g}$ glucose load, agrees with the $40 \pm 3 \mathrm{~g}$ reported by Felig et al. (1975). The concordance between these results suggests, on the 


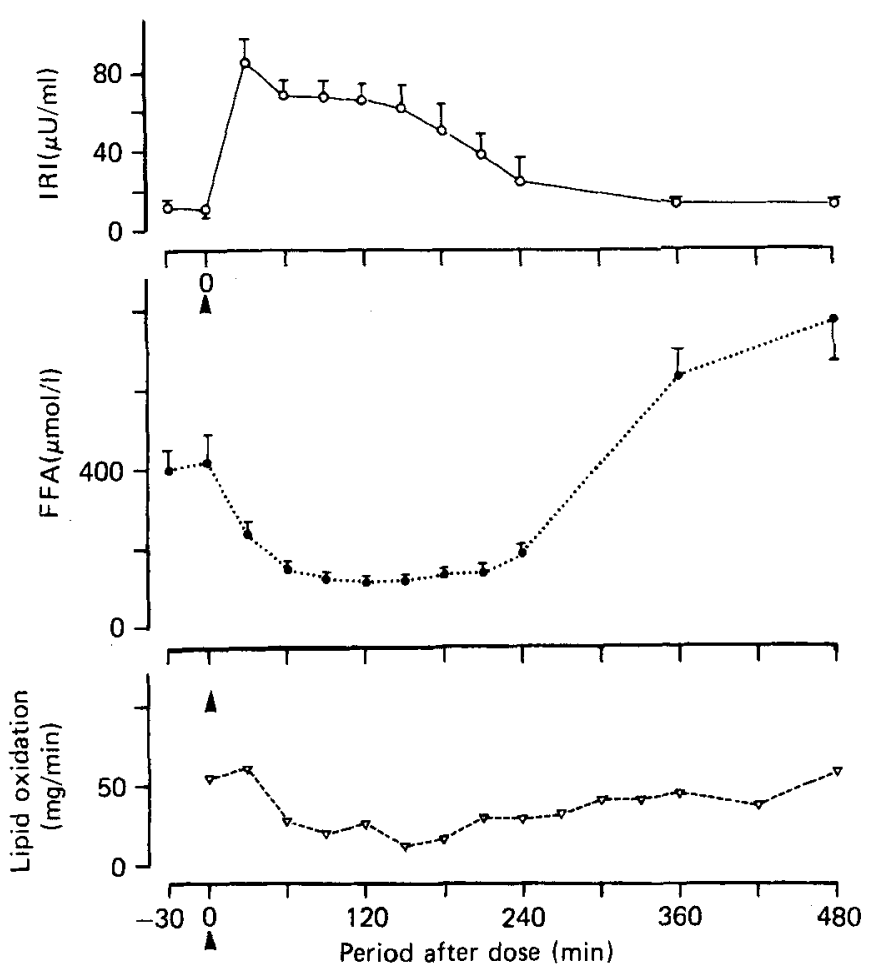

Fig. I. Measurement, in five healthy adult subjects, of carbohydrates (CHO) and lipid utilization rates $(\mathrm{mg} / \mathrm{min})$ by indirect calorimetry $(\mathrm{O}-\mathrm{O})$, and glucose oxidation by mass spectrometry (๑---) after $100 \mathrm{~g}$ naturally-labelled $\left[{ }^{13} \mathrm{C}\right]$ glucose load, corresponding plasma glucose (mg/l), immunoresponsive insulin (IRI) and free fatty acid (FFA; $\mu \mathrm{mol} / 1$ ) levels. $\downarrow$, glucose load. Points represent mean values, with their standard errors represented by vertical bars.

one hand, that the major part of the hepatic glucose output is oxidized, and on the other, that little glucose is oxidized in the liver.

A slight increase in the total energy expenditure was observed with a maximum between 60 and $90 \mathrm{~min}(5.77 \pm 0.29 \mathrm{~kJ} / \mathrm{min} v .4 .86 \pm 0.2 \mathrm{I} \mathrm{kJ} / \mathrm{min}$ in the basal state).

From the results, it can be seen that there is a delay in $\mathrm{CHO}$ utilization measured by mass spectrometry when compared to that measured by indirect calorimetry. This cannot be interpreted as a preferential oxidation of endogenous glucose over that of exogenous origin, since Steele, Bjerknes et al. (1968), de Bodo et al. (1963), Searle \& Chaikoff (1952) and Madison et al. (1963) have demonstrated in the dog that there is a reduction in hepatic glucose output after a glucose load, as a result of increased insulin secretion, and that when glucose is taken orally hepatic glucose output is reduced over the period of active glucose absorption, i.e. approximately $3 \mathrm{~h}$ (Steele, Bjerknes et al. 1968). Therefore, there must be an early oxidation of exogenous glucose which bypasses the liver as well as oxidation of endogenous glucose in the peripheral tissues.

This delay can be accounted for by dilution of the administered $\left[{ }^{13} \mathrm{C}\right]$ glucose in the endogenous glucose pool (Steele et al. 1956 ) and further dilution of ${ }^{13} \mathrm{CO}_{2}$ in the bicarbonate pool after glucose oxidation (Steele et al. 1959).

In the resting state, it took $4.5 \mathrm{~h}$ to reach peak ${ }^{13} \mathrm{CO}_{2}$ enrichment. Whilst correction factors have been determined for this non-steady state period in dogs (Steele, Winkler et 


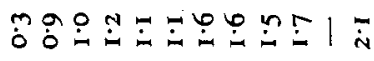

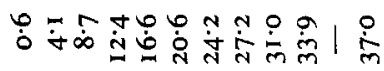

ڤn

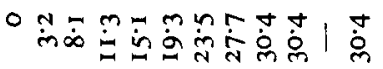

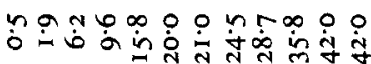

อัด

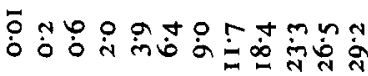

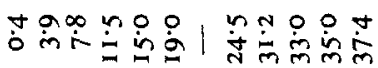

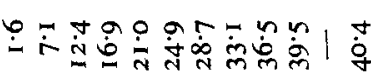

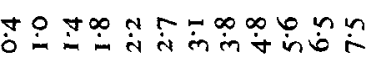

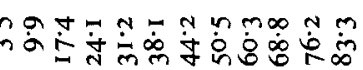

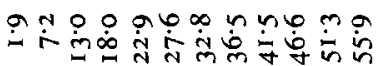

壱

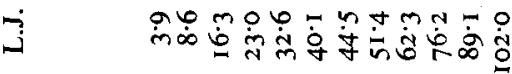

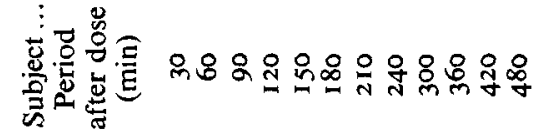

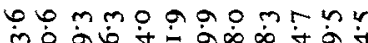

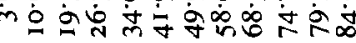

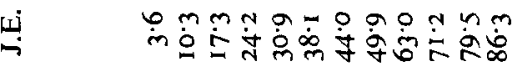

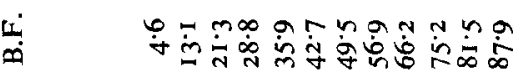

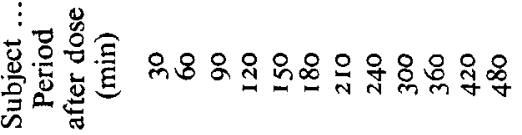




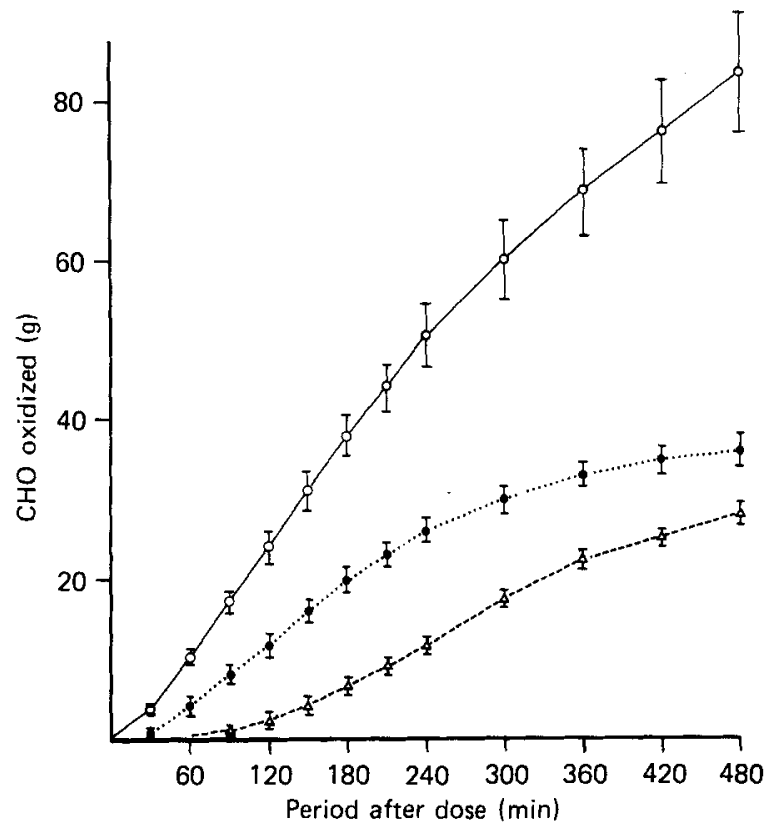

Fig. 2. Cumulative values for carbohydrate (CHO) oxidation $(\mathrm{g})$ after $100 \mathrm{~g}$ oral $\left.{ }^{[3} \mathrm{C}\right] \mathrm{glucose}$ load in five healthy adult subjects. $(\mathrm{O}-\mathrm{O})$, cumulated $\mathrm{CHO}$ oxidation values measured by indirect calorimetry; ( $\cdots \cdot$ ), cumulated $\mathrm{CHO}$ oxidation values above basal oxidation levels, measured by indirect calorimetry; $(\Delta--\Delta)$, cumulated $\left[{ }^{13} \mathrm{C}\right]$ glucose oxidation measured by mass spectrometry. Points represent mean values, with their standard errors represented by vertical bars.

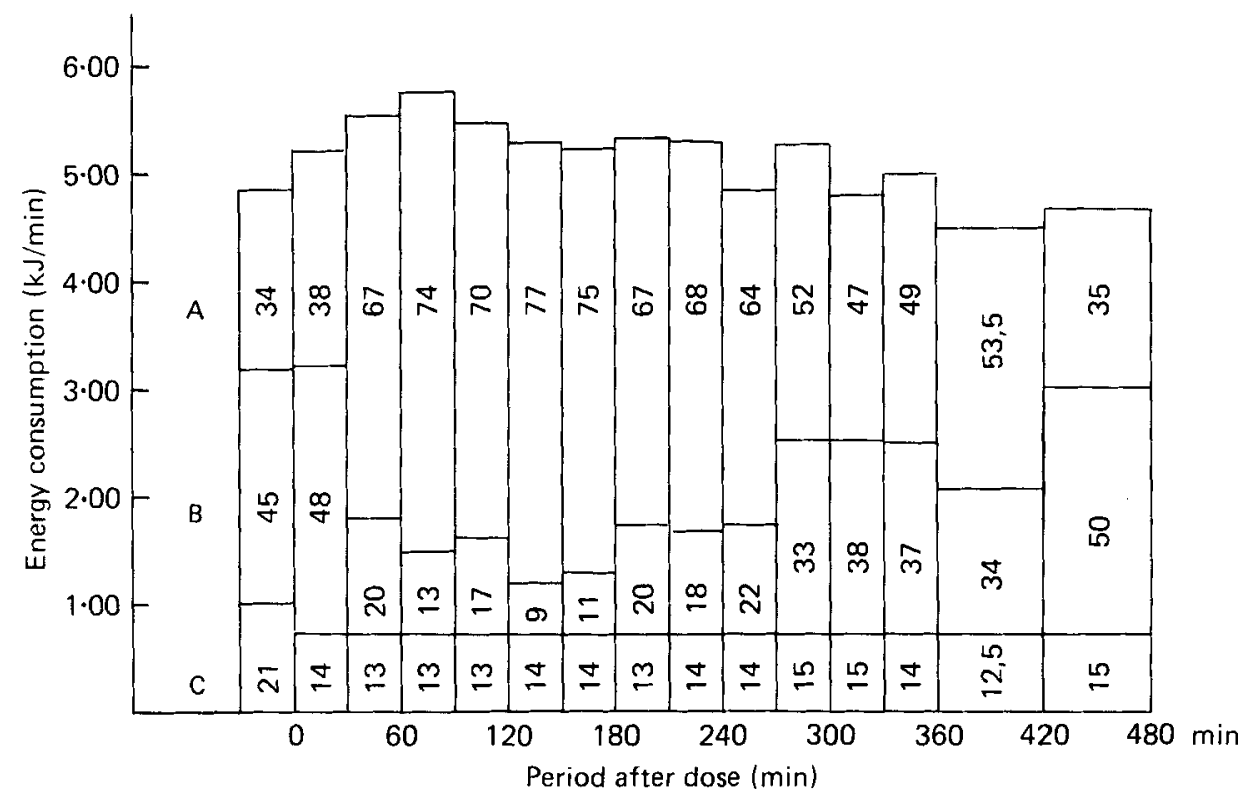

Fig. 3. Relative contribution (\%) of proteins (A), lipids (B), and carbohydrates (CHO) (C), to energy consumption $(\mathrm{kJ} / \mathrm{min})$ for periods of $30-60$ min before and after a $100 \mathrm{~g}$ oral glucose load. Values were calculated from the urinary nitrogen and non-protein respiratory quotient. 
al. 1968), their application to human studies is questionable. It is possible to accelerate the turnover and mixing of these pools by exercise (Vranic \& Wrenshall, I969).

After its peak at $270 \mathrm{~min},\left[{ }^{13} \mathrm{C}\right]$ glucose oxidation runs parallel to the total CHO oxidation. Cumulative values show that exogenous glucose provides approximately onethird of the total $\mathrm{CHO}$ oxidized and three quarters of the $\mathrm{CHO}$ oxidized above basal values.

Indirect calorimetry showed a return of total $\mathrm{CHO}$ oxidation to its baseline value at $480 \mathrm{~min}$, at which time the total amount of glucose oxidized above basal values was $37 \mathrm{~g}$. At $480 \mathrm{~min},\left[{ }^{13} \mathrm{C}\right] \mathrm{glucose}$ oxidation was $28 \mathrm{~g}$, but baseline values had not been reached. If the experiments had been extended so that the ${ }^{13} \mathrm{CO}_{2}$ concentration had returned to its baseline value, it would have been possible to calculate the number of $\left[{ }^{13} \mathrm{C}\right]$ glucose- $\mathrm{C}$ atoms which had become ${ }^{13} \mathrm{CO}_{2}-\mathrm{C}$ atoms. At such a time the error due to ${ }^{13} \mathrm{CO}_{2}$ mixing in the bicarbonate pool has been corrected, since the pool has regained its original composition.

A criticism of the method of indirect calorimetry in evaluating substrate utilization, is the influence of lipogenesis on the NP-RQ.

Whilst it is unlikely that lipogenesis occurred under the conditions of the test, in which the glucose load was preceded by a IO-I 2 h fast, it is of interest to attempt to clarify this point.

It has been shown since the early I900s that NP-RQ values exceeding unity are possible (Lusk, 1924) and that they represent net conversion of CHO to lipid. The NP-RQ is only greater than I.O when lipogenesis exceeds lipolysis, i.e. when there is a net transfer of $\mathrm{C}$ atoms from $\mathrm{CHO}$ to lipids. When the NP-RQ is high but less than unity, it can be shown that $\mathrm{CHO}$ and lipid oxidation may take place at the same time as lipid synthesis. Lusk (I924) ignored the possibility that lipogenesis may occur at an NP-RQ of less than unity when he derived his equations for calculating $\mathrm{CHO}$ and lipid oxidation. Recent stoichiometric calculations for the energy release within the range of respiratory quotient values from 0.7 to 1.0 yield identical values whether $\mathrm{CHO}$ and lipid occur in the absence or in the presence of lipogenesis (J. P. Flatt, personal communication). The equations of Lusk (I924) are thus valid in the presence or in the absence of lipogenesis up to NP-RQ values of $1 \cdot 0$.

Thus it is possible to conclude that of a $100 \mathrm{~g}$ (naturally-labelled) $\left[{ }^{13} \mathrm{C}\right] \mathrm{glucose}$ load, approximately $30 \%$ are oxidized and $70 \%$ stored during the $8 \mathrm{~h}$ after ingestion. The stimulation of $\mathrm{CHO}$ oxidation by the load is largely due to that part of the load which is oxidized, i.e. $29 \mathrm{~g}\left[{ }^{13} \mathrm{C}\right] \mathrm{glucose}$ of $37 \mathrm{~g} \mathrm{CHO}$ oxidation above basal values.

This work was partly supported by the Fonds Rayment Berger pour la Recherche sur le Diabète, Lausanne, Switzerland.

\section{REFERENCES}

Baker, N., Schreeve, W. W., Shipley, R. A., Incefy, G. E. \& Miller, M. (1954). J. biol. Chem. 211 , 575. Beloff-Chain, A., Catanzaro, R., Chain, E. B., Masi, I., Pocchiari, F. \& Rossi, C. (1955). Proc. R. Soc. I43, 48I.

Craig, H. (1957). Geochim. cosmochim. Acta r2, 133.

De Bodo, R. C., Steele, R., Altszuler, N., Dunn, A. \& Bishop, J. S. (1963). Diabetes 12, 16.

Dole, V. P. \& Meinertz, H. (1960). J. biol. Chem. 235, 2595.

Eaton, P. \& Steinberg, D. (1961). J. Lipid Res. 2, 376.

Felber, J. P., Magnenat, G., Casthélaz, M., Geser, C. A., Müller-Hess, R., de Kalbermatten, N., Ebiner,

J. R., Curchod, B., Pittet, Ch. \& Jéquier, E. (1977). Diabetes 26, 693.

Felig, Ph., Wahren, J. \& Hendler, R. (I975), Diabetes 24, 468.

Gomez, F., Jéquier, E., Chabot, V., Büber, V. \& Felber, J. P. (1972). Metabolism 21, 381. 
Hales, C. N. \& Randle, P. J. (1963). Biochem. J. 88, 137.

Heindel, J. J., Cushman, S. W. \& Jeanrenaud, B. (1974). Am. J. Physiol. 226, I6.

Lefebvre, P., Mosora, F., Lacroix, M., Luyckx, A., Lopez-Habib, G. \& Duchesne, J. (I975). Diabetes 24, 185 .

Lusk, G. (1924). J. biol. Chem. 59, 41 .

Madison, L. L., Mebane, D., Lecocq, F. \& Combes, B. (1963). Diabetes 12, 8.

Metropolitan Life Insurance Company (1959). Stat. Bull. 40, 40.

Mosora, F., Lefebvre, P., Pirnay, F., Lacroix, M., Luyckx, A. \& Duchesne, J. (1976). Metabolism 25, I 575 .

Müller-Hess, R., Geser, C., Pittet, Ph., Chappuis, P., Jéquier, E. \& Felber, J. P. (1975), Diabetes Metab. I, 15 I.

Searle, G. L. \& Chaikoff, I. L. (1952). Am. J. Physiol. 170, 456.

Searle, G. L., Strisower, E. H. \& Chaikoff, I. L. (1956). Am. J. Physiol. 185, 589.

Slein, M. W. ( 1965 ). In Methods of Enzymatic Analysis, 2nd ed., p. I 17 (H. W. Bergmeyer, editor). Weinheim: Verlag Chemie.

Smith, B. N. \& Epstein, S. (1971). Pl. Physiol. 47, 380.

Steele, R., Altszuler, N., Wall, J. S., Dunn, A. \& De Bodo, R. C. (I959), Am. J. Physiol. 196, 221.

Steele, R., Bjerknes, C., Rathgeb, I. \& Altszuler, N. (1968). Diabetes 17, 415.

Steele, R., Wall, J. S., De Bodo, R. C. \& Altszuler, N. (1956). Am. J. Physiol, r87, I5.

Steele, R., Winkler, B., Rathgeb, I., Bjerknes, C. \& Altszuler, N. (1968). Am. J. Physiol. 214, 313.

Vranic, M. \& Wrenshall, G. A. (1969). Endocrinology 85, 165. 